PAWEL ZYGADEO

\title{
FACE AND COMMUNICATION IN CHINESE CONTEXT
}

\section{Introduction}

The notion of face (mianzi, 面子; lian, 脸), has long been seen as an essential element of Chinese culture. As David Yao-fai Ho argued "It is virtually impossible to think of a face of [Chinese] social life to which the question of face is irrelevant."1 Much earlier Hu Hsien-Chin insisted that "The study of concept of 'face' in China reveals two sets of criteria by which prestige is gained and status secured or improved, and also how different attitudes can be reconciled within the framework of the same culture."2 Hwang Kuang-Kuo utilising social exchange theory claimed that proposed by him Face-Favour-Guanxi complex as a power game framework "depicts not only a prototype of social behaviour in Chinese society but also a general model for illustrating the process of social interactions in most cultures, especially that in a collectivist culture."3 Similarly, Stella Ting-Toomey identifies face-giving, other directed-face and face-honouring as an important component of the collectivist cultures, that should be approached as a relational part of the face-negotiation model. ${ }^{4}$ Another interesting assertion has been made by Wenshan Jia for whom face and facework, ${ }^{5}$ is "a typical Chinese conflict-preventive mechanism and a primary means to cultivate harmonious human relations in Chinese social life." 6

Without going into the more in-depth analysis, we can conclude that there are at least two aspects of this phenomenon that might require further investigation. First, despite some negative aspects of this notion, face remained a vital element

\footnotetext{
1 D.Y.F. Ho, On the Concept of Face, "American Journal of Sociology" 1976, vol. 81, no. 4, p. 883.

2 H.C. Hu, The Chinese Concept of "Face", "American Anthropologist" 1944, vol. 46, p. 44.

3 K.K. Hwang, Face and Favor: The Chinese Power Game, "American Journal of Sociology" 1987, vol. 92 , no. 4, p. 945.

4 S. Ting-Toomey, Intercultural conflict styles: A face negotiation theory [in:] Theories in intercultural communication, eds. Y.Y. Kim, W.B. Gudykunst, Sage, Newbury Park, CA 1988.

5 Term introduced by Erving Goffman in his essay On Face-work (1955) [in:] idem, Interaction Ritual: Essays on Face-to-Face Behavior, Anchor Books, New York 1967.

${ }^{6}$ W.S. Jia, Facework as a Chinese Conflict-Preventive Mechanism - A Cultural/Discourse Analysis, "Intercultural Communication Studies" 1997-1998, vol. 7, no. 1.
} 
of Chinese socio-cultural life. ${ }^{7}$ Another conclusion of the up-to-date research is the fact that face is an essential factor deciding the manner of communication, personal and group sympathies and disdains, and even influencing juridical processes in Chinese society. It appears that without considering one's own and others' face, the ability to comprehend and communicate the knowledge about oneself and others is or would be somehow deficient in Sino-cultural context. To be more specific, in Chinese context it is quite hard to imagine a situation in which all the personal and professional titles would be abandoned, a fondness of others' acknowledgement skipped and the "shaming" of the one who, at least superficially, do not respect socio-cultural norms disregarded. At least for someone familiar with the Chinese language and accustomed to Chinese-style social relations, an evolution of Chinese society towards such a "rationalised" form of social communication is hardly imaginable. The practical application of the notion of face and its pervasiveness seem to be a display of culturally determined tendencies in Chinese communication. On the other hand, they are an articulation of a need for a specific "medium," a tool that not only makes the exchange possible but can structure the way it is carried on. This "mediatory" and "structuring" function of the notion of face, or rather it is practical application is the subject of the interest in this paper.

\section{The notion of face in contemporary science}

The concept of face became a researched subject due to the contacts with the Western world. The first relatively comprehensive, although not written without prejudice, description of the phenomenon came from the American missionary, Arthur Henderson Smith (1845-1932). In Chinese Characteristics he provided probably the first account on the notion of face known to the Western world. He listed it among other features that he considered crucial for understanding Chinese and their culture. Smith then argued that face is "a key to the combination lock of many of the most important characteristics of the Chinese." ${ }^{\prime 8} \mathrm{He}$ believed that Chinese appreciation of face, is derived from Chinese taste for theatrical performance, the mask that is in dire contrast to what Westerners perceive as "reality" and "fact," and as such "deserving only to be abolished and replaced by common sense." Many among revolutionaries of the early $20^{\text {th }}$ century, such as Lu Xun

7 X. Lu, Lu Xun Quanji [Collected Works of Lu Xun], Renmin Wenxue, Beijing 1981; Y.T. Lin, My Country and My People, Reynal \& Hitchcock, Inc., New York 1935.

8 A.H. Smith, Chinese Characteristics, Revell, New York 1894, p. 17.

$9 \quad$ Ibidem, p. 17. 
or Lin Yutang came up with a similar critique of Chinese face. ${ }^{10} \mathrm{Lu}$ Xun, for instance, depicted "Chinese national character" as self-deceiving, ruthless, obsessed with what would we call social recognition and "human's flesh consuming" (狂人 日記). ${ }^{11}$ Even he could not define what precisely the face was, Lu Xun perceived face an integral element of the whole system, that, as he argued should be entirely abandoned. ${ }^{12}$ Another prominent intellectual of the time, Lin Yutang, in his My Country and My People, argued that China is ruled by the triad of "Face, Fate and Favour." These three, with the Face as a dominant one prevent China from the expulsion of corruption and implementing the rule of law and reason. Only if these notions, especially face are abandoned, justice and reason will prevail. ${ }^{13}$ On the other hand, following from the success of Smith's book, sinologist such as John MacGowan, went deeper with the analysis of the phenomenon. Macgowan similarly to Smith emphasised "theatrical nature of Chinese face. ${ }^{14}$ However, he not only exemplified two aspects of this notion, "honour and reputation" vs "self-respect and dignity," but also tried to disassociate the term with the "inferior nature of the Chinese."15 Hu Hsien-Chin, possibly drawing on MacGowan's work, further developed the idea of actually two aspects of face. In probably the first scientific paper entirely dedicated to the notion of face, she analysed two notions that only in English rest under the same term, face. Hu then clarifies: "(...) mien-tzu (mianzi), stands for the kind of prestige that is emphasized in this country: a reputation achieved through getting on in life, through success and ostentation.” And further: “(...) lien (lian), ... is the respect of the group for a man with a good moral reputation: the man who will fulfil his obligations regardless of the hardships involved, who under all circumstances shows himself a decent human being."16

What is noteworthy, is the fact that while acknowledging negative aspects of Chinese face, prestige and social image, $\mathrm{Hu}$ points to the psycho-moral sources of the phenomenon. It might be arguable if mianzi and lian are separate entities, but the importance of two dimensions of Chinese face should not be overlooked. ${ }^{17}$

10 Arthur H. Smith was not alone in associating face with "inferior nature of the Chinese" which Westerners liked to define as "cunning, sly, having no taste for honesty and directness" etc. More on this see: J.St. André, How the Chinese lost 'face', "Journal of Pragmatics" 2013, vol. 55, pp. 68-85.

11 "But what is this thing called face is? It is very well if you don't stop to think, but the more you think the more confused you grow." X. Lu, Lu Xun Quanji [Collected Works of Lu Xun], Renmin Wenxue, Beijing 1981, p. 129.

12 Ibidem, pp. 75-76.

13 Y.T. Lin, My Country ..., pp. 191, 343.

14 J. MacGowan, Men and Manners in Modern China, Unwin, London 1912.

15 J. St. André, How the Chinese lost 'face'..., p. 70.

16 H.C. Hu, The Chinese Concept..., p. 45.

17 D.Y.F. Ho, On the Concept of Face...; J. St. André, How the Chinese lost 'face'... 
David Ho in his analysis of face, points out that delineation between mianzi and lian is of a little different nature that Hu would like to see it. He insists that mianzi is not altogether devoid of moral aspect. Moreover, emphasis on the linguistic, and semantic difference between lian and mianzi is not quite justified since some relevant terminology can be used interchangeably. So the distinction as define by $\mathrm{Hu}$ is more of "technical" nature that an essential difference between the two. ${ }^{18}$ Subsequently, Ho tries to define face on his one terms, by pointing out what face is not. Face is then not "a standard of behaviour," "a personal variability," "status, dignity or honour" or "prestige." 19 What is the face then? As Ho states: "Face is the respectability and/or deference which a person can claim for himself from others, by virtue of the relative position he occupies in his social net-work and the degree to which he is judged to have functioned adequately in that position as well as acceptably in his general conduct (...)."20

Hwang Kuang-Kuo makes face into an integral part of the complex structure consisting of face, renqing (favour) and guanxi (social relations). The whole complex is based on an appeal to social ties, expressive, instrumental and mixed, regulates goods, tangible or intangible, exchange. ${ }^{21}$ Face is then a resource that can be "exchange" for something else, as a "cash-back" or a claim from a Petitioner to the Resources Allocator (terminology used by Hwang) for "greater" portion of the good claimed. Moreover, it also allows social structuralisation and makes such a structure recognisable. ${ }^{22}$ Other researchers, for instance, Stella Ting-Toomey insist that face-giving, other directed-face and face-honouring are part of the face-negotiation model that is an essential component of the collectivist cultures. ${ }^{23}$ For Ron Scollon and Suzanne Wong Scollon face should be as "interpersonal identity of individuals in communication" and the "self as a communicative identity." 24 Wenshan Jia, on the other hand, insists that face and facework is "a typical Chinese conflict-preventive mechanism and a primary means to cultivate harmonious human relations in Chinese social life." ${ }^{25}$ Mainland Chinese researchers, such as Zhai Xuewei and Zuo Bin, although representing slightly different approaches, sociology and social psychology respectively, in terms of methodology, on the one hand, follow $\mathrm{Hu}$, on the other Tai-

18 D.Y.F. Ho, On the Concept of Face..., p. 868.

19 Detailed analysis: ibidem, pp. 874-880.

20 Ibidem, p. 884.

21 K.K. Hwang, Face and Favor..., pp. 944-949.

22 Ibidem, pp. 960-962.

23 S. Ting-Toomey, Intercultural conflict styles...; eadem, Translating conflict face-negotiation theory into practice [in:] Handbook of intercultural training, eds. D.R. Landis, J.M. Bennett, M.J. Bennett, Sage, Thousand Oaks, CA 2004; eadem, The Matrix of Face: An Updated Face-Negotiation Theory [in:] Theorizing About Intercultural Communication, ed. W.B. Gudykunst, Sage, Thousand Oaks, CA 2005, pp. 71-92.

${ }^{24}$ R. Scollon, S.W. Scollon, Intercultural communication: a discourse approach, Blackwell Publishers, Malden, MA 2001, pp. 34-36.

25 W.S. Jia, Facework as a Chinese Conflict... 
wanese research. ${ }^{26}$ Zhai, for instance, similarly to Hwang associates face with power and favours seeing this as an essential structure of Chinese social and communicational culture. ${ }^{27}$ In his later work, he summarises face as a "self-evaluation and psychological position in other's mind." ${ }^{28}$ Zuo, on another hand, insists, that despite the fact that the notion of face applies to other cultures, in Chinese minds it occupies a special place, a way more significant that in case of Westerners. ${ }^{29}$ Face, especially lian is a central component of Chinese personality. It is not only a component that is involved with social positioning and communication but is a very essence of individual identity in Chinese society. ${ }^{30}$ Helen Spencer-Oatey, on her behalf pointed out to the more general and at the same time cognitively more basic aspect of Chinese face. As she states: "I propose that in cognitive terms, face and identity are similar in that both relate to the notion of 'self'-image (including individual, relational and collective construals of self), and both comprise multiple self-aspects or attributes. However, face is only associated with attributes that are affectively sensitive to the claimant. It is associated with positively evaluated attributes that the claimant wants others to acknowledge (explicitly or implicitly), and with negatively evaluated attributes that the claimant wants others NOT to ascribe to him/her." ${ }^{11}$

In her later work Oetey, she presented how these principles apply to a real-life situation where the power and the recognition of moral and social statuses become the primary concerns of the interactants. ${ }^{32}$

\section{"Do you know who I am?!" - face and in practice}

Face is a social phenomenon, which as Lin Yutang pointed out used to be one of the powers "ruling" Chinese society for centuries. As modernity progressed, the notion

26 X.W. Zhai, Zhoongguoren de lianmianguan [The Chinese and the Concept of Face], Guiguan, Taipei 1995; idem, Renqing, mianzi yu quanli zai shengchan - qingli shehui de juaobuan fangshi [Favor, face and reproduction of the power: a way of social exchange in a reasonableness society], "Shehui yanjiu" [Social Research] 2004, no. 113, pp. 48-57; idem, Renqing, mianzi yu quanli zai shengchan [Favor, face and reproduction of the power], Peking University Press, Beijing 2013; B. Zuo, Zhongguo ren de lian yu mianzi [Lian and mianzi of the Chinese], Central China Normal University Press, Wuhan 1997; H.C. Hu, The Chinese Concept...

27 X.W. Zhai, Zhoongguoren...

28 X.W. Zhai, Renqing, mianzi..., p. 55.

29 B. Zuo, Zhongguo ren..., p. 51.

30 Ibidem, p. 60.

31 H. Spencer-Oatey, Theories of identity and the analysis of face, "Journal of Pragmatics" 2007, vol. 39, issue 4, p. 644 .

32 J.Y. Wang, H. Spencer-Oatey, The gains and losses of face in ongoing intercultural interaction: A case study of Chinese participant perspectives, "Journal of Pragmatics" 2015, vol. 89, pp. 50-65. 
of face has been re-evaluated. At first, it was objectified and became a subject of further inquiry. Second, that "newly-discovered" ancient characteristic of the Chinese, was negatively valued, and as such the calls for erasing face from Chinese character were vocalised. We could expect that as the modernising movements took the lead in Chinese politics and social reforms, the remnant notions of the past should be gone. However, is the notion of face gone from Chinese social and even political life? Is the communication in contemporary Chinese society, with all its advancements and rationalisation efforts, utterly void of face factor? Having a look at the number of the published after Hu's first paper research regarding this issue, the answer cannot be definite. The methodology applied in this study, besides textual analysis will be the analysis of the material that I was able to obtain as an interpreter in situations that by the nature of the matter, created opportunities for authority, social positioning and face display. To illustrate how vivid and persistent the notion of face is in contemporary China, and to test above theories I will shortly analyse the case of police interrogation that I was involved as an interpreter. Due to the limits of this work, I will not analyse other cases of similar events. However, as I will try to present, the variety of meanings and applications of the notion of face that have been displayed provide enough material for the examination of the theories mentioned above, and the analysis of other cases can be omitted. At least at this occasion.

\section{Background}

G, British ESL tutor accused by one of the students of taking inappropriate pictures of hers, had been summoned to the police station near the school where he worked. As the interrogation started, it turned out that the officer in charge of visas for all foreigners in the district was in attendance. Initially, the hearing was scheduled for 14:00. Due to the interpreter schedule, the police agreed to wait until 14:30. G was accompanied by his wife, Asian but not Chinese, his line manager and unexpectedly the Head of the HR department. The report below was completed just after the interrogation. It contains directly translated from Chinese text with only the most offensive words omitted.

\section{Procedure}

After waiting for almost twenty minutes, G's wife, that can speak Chinese asked one of the lower rank policemen how long it was going to take to see the investigators. The harsh reply was "As long as it is necessary." The atmosphere was becoming more and more nervous, partly due to the rather unpleasant situation, partly due to the G's anxieties (he suffers from minor anxiety disorder and a certain degree of claustrophobia). After another ten minutes, three higher rank officers entered the room, one around fifty years old (later as W, since he spelt out his surname), two others around 
thirty years old (Y1 and Y2, they did not introduce themselves). The older officer started with an ostensive display of authority and immediate claim for status recognition asking few times if the foreigners present in the room knew who he was. Neither G nor his interpreter, manager or wife did know W (Head of the HR department stayed outside waiting for someone else to bring some additional documentation). Then he shouted that he was officer W that was "giving them visas" and that he was in the power of cancelling all of them right away. From the very begging, $\mathrm{W}$ and Y1 were loud and not very friendly. Especially Y1 was about to display very aggressive and uncompromised attitude during the entire interrogation. Then $G$ was asked for the passport that, strangely enough, he did not bring. Officers quite harshly asked him to go home and bring it. It was the moment when his wife started directing questions towards W about how long it was going to take and stated categorically that her husband could not stay for long. It made W shouting and infuriated Y1. Y1 began yelling at her "Follow the orders! Follow the orders! This is China, not your bloody (name of the country that for the sake of anonymity must be omitted here)! Go, go!" (his actual words spoken out in English). She tried to fight back, what made the situation even worse. The interpreter intervened, apologising to the officers, especially W who was the real man in charge, and forcing G's wife out of the room. She left for G's passport. The interpreter immediately came back to the room, where $G$ and his manager were still sitting. Again he apologised to the officers "ensuring" W that G will be cooperating, and there is no need to be unhappy about the whole situation, that "was all foreigners fault." He also verbally acknowledged the importance of W position and 'sincerely' thanked him for all the help all the foreigners working in the entire district received from him. W's face changed, he started smiling and praising the interpreter for his language skills and understanding of "magnificent and long-lasting" Chinese culture. The interpreter denied all of this, saying that W was far way too kind and that he and $G$ came to humbly learn from such an exquisite person like W. Y2 was rather relaxed by the time, but Y1 was still extremally unfriendly. W asked then $\mathrm{G}$ and interpreter to move to the interrogation room. In Chinese interrogation rooms, there are special wooden chairs with a desk in front that "closes" the suspects on it. According to the regulations, the suspect needs to sit on one during the whole time of being asked questions. The interpreter had been warned that for $G$ it would be unbearable to stay locked like that even for short period of time. After entering the room and seeing the chair, G got extremally frightened, and being disoriented did not know what to do. When he tried to sit, with a grimace of pain on his face, he was shouted at again by Y1, who wanted his backpack, and all the belongings from his pockets. At this point, police officers tried to follow the procedure, but they did not inform $G$ about them in the first place, and the way they proceeded did not make the situation easier. The interpreter ran to $\mathrm{W}$ and tried to explain that it would be extreme stress for $\mathrm{G}$ to sit on that chair. Y1 reacted with verbal aggression, shouting that "It is a rule in China! Shut up and sit! It is a rule!" The interpreter kept asking W for permission not 
to sit on that chair and possibility of having the whole thing being done in another room. He also "sincerely" apologised for the entire situation, and tried to ensure that moving $G$ to another room without such a chair would make him more relaxed and the whole process would go more smoothly. Y1 was still shouting, but W agreed. Y1 tried to protest, but $\mathrm{W}$ asked him to stop.

The formal interrogation started. The first question came from $\mathrm{W}$, and he tried to ask it in English. He took pride in the fact that he could speak English, although his abilities in this respect were quite limited. "You know why you here?" - G confirmed that he did. "So, why did you do it?" - W continued in Chinese. "I did not" - G tried to protest. "Don't you lie to us! I can kick you out of the country right away! You will be flying out of China tomorrow!" "But, I did not do anything wrong. I don't even know, ..." The exchange was going nowhere, so the interpreter, intervened, trying to push the whole discussion to another direction. "Mr W, I do apologise for my boldness and lack of experience in the matter, but maybe that student made a mistake, overreacted to a new situation, something she did not see before...? I would never dear to instruct professionals, but maybe we could try to listen to what, according to $G$ possibly happened?" "What could happen? If he didn't do it, that student wouldn't come to us!" - Y1 shouted angrily. Interpreter ignored him since he was not the one in charge, and any comments regarding his words would probably catch interpreter in a raw with him. Interpreted continued talking to $\mathrm{W}$, and $\mathrm{W}$ agreed to listen to $\mathrm{G}$. $\mathrm{G}$ told them about his teaching habits (during the first class, he takes pictures of the entire class, with students' consent, prints it and writes the students names. It allows him to remember their names much easier), and also about his disorders and some habits related to them. For instance, he holds phone in his hand basically all the time, so he can call his wife once he does not feel well. W got interested in $\mathrm{G}$ teaching practices but dismissed disorders as a possible source of misunderstanding. W wanted to know more, but he also kept insisting that G must tell the truth. "If you tell the truth, then maybe we can still figure out something for you. You lie to me, and you are busted! Understand? Understand?!" W kept repeating: "He is lying all the way through!" Y1 shouted at G, making him more nervous. "We do understand the severity of the situation, he would never dear to lie to you, Sir." - the interpreter kept ensuring W. W started asking about details, how he takes those pics and why. $G$ explained few times, and it seemed that he made W being sympathetic. $Y 2$ was all the time in the room, not talking much, besides telling $\mathrm{G}$ to sit after he entered the room, asking him for his name. In the meantime G's wife came back with his passport. The manager came with her to the interrogation room. She showed G's passport and was also asked to show hers. Then Y1 asked them to leave and interpreted rushed to stop G's wife from getting into another raw with him. $\mathrm{G}$ was very stressed. After $\mathrm{W}$ had heard everything about the G's methods, he said to the interpreter "It is not a crime, but a damn silly thing to do it! What was he thinking? Tell him not to do it again, or he will be in trouble again." Then W had an idea: "If you are not lying, you must have pictures from previous years somewhere, don't 
you?" - he asked. "Yes" - G replied - "I do have them on my computer." "Excellent then. We want to see it. Let's go to your office." - G was startled. "What? So it means that students can see me escorted by the police?! No! My reputation will be ruined! They are going to jail me, no, no! I don't want it!" - he started behaving abruptly. It made all three policemen suspicious again. The interpreter asked $G$ to stay calm and immediately agreed on his behalf. Three police officers, $G$ and the interpreter, took the police car. $G$ was extremally nervous, but he has explained that it was the only way to get things sorted. After they had reached the school, they went to G's office. There were not many students of the way, just three. Once they entered the room, G showed them everything. W said: "I am quite convinced. Yeah, you are not a criminal, just a silly foreigner. Really silly. Kids now are different, spoiled; you must watch out with them." He asked G and interpreter to go with them to the police station again. Upon arrival, $W$ asked $G$ to repeat the answers to the main questions and tell $Y 2$ to make a formal report. $Y 2$ was asking question by question, $G$ was answering, $Y 2$ was typing. $\mathrm{W}$ and $\mathrm{Y} 1$ had left the room before they started. Once it was almost done, they came back again. "What about your phone?" - asked W. "You can still be lying. Maybe you deleted stuff from your computer, and maybe even from the phone. But we have technology that can check if you had any inappropriate pictures on your cell. So the last chance, tell us the truth, or you will be trouble." "But I just have" - desperate G tried to protest. "Don't mess with me!" - W said. "I told you he was a liar" Y1 repeated for nobody-knows-what time. "Ok, listen up" said W - "I actually want to help you. I want to prove that you are innocent. Do you understand that?" - G nodded his head. "So, you must give us your phone, for inspection." G got absolutely startled again. "But they don't have right to do it" he said to the interpreter. "So you won't cooperate?" - W asked. "What will happen if he refuses to leave his cell with you?" interpreter asked immediately. W's face changed again. "I will write that he didn't want to cooperate. I will have a warrant by tomorrow morning, and he will have to give it to us." "Give it to Mr. W" - interpreted urged G "But,..." - G tried to protest. "Just do it. It will be worse if you do not." They took the phone and promised to give it back after inspection, what should not take them more than a week. After all courtesies, they all were allowed to leave. Upon leaving, $W$ asked the interpreted for the phone number. "We will phone you about the development of the situation. You seem to understand the importance of our work." "Certainly, sir" - the interpreter answered. "I am very sorry for their behaviour, especially G's wife; it was not appropriate." "Precisely! She was totally out of her mind. What was she thinking? Maybe in her country they do not understand rules, but not here in China! Anyhow, everything should be fine." The interpreter gave him his name card. "Wow, you are an Aspro?!" - he smiled surprised. "That's great, it's really nice to meet you!" - he patted interpreter's shoulder. "Really nice! We must have some dinner sometimes! It would be nice, wouldn't it?" "Yes, of course" the interpreter answered friendly. "Anytime you have time!" - "I will let you know! You know, we just try to help, but these people... Not only they do not see that 
we actually care about them, but they don't know how to behave. Who they think they are? It is really nice talking to you and you are a professor! Really nice." W repeated and left. The whole group from University, altogether 5 people left the police station.

A week later, interpreter received a call from the police, asking him to bring $G$ to the same police station. Upon arrival, $G$ and the interpreter were taken to the same room as previously, and Y2, the friendliest of the three came in. He informed everyone that nothing has been found and that the police will not proceed with any further investigation. He urged $G$, through an interpreter to take some time off to calm down and not to try to seek any revenge on the student. She could be silly, and the school discusses the matter with her and her parents. However, if G goes for any legal actions then "the whole thing can turn ugly, and nobody wants that. Especially since the student is Chinese."

\section{Discussion}

Before we proceed with the conclusions that can be drawn from the above description, it is worthy to analyse the whole situation again. So as the interrogation starts, two extremally important factors shaped the further procedure. The first one was the fact that none of the persons taken to the interrogation room knew the status of W. The only person that due to the nature of her work knew who W was, was the Head of HR department. She, however, did not inform any of the three entering the room about it. She knew that he was going to come, as it was learnt later, but she did not provide any information about him. Providing the interpreter with relevant information would probably be a display of subordinate status, and she would do everything but accepting such arrangement. The second event that almost cost $G$ night in jail was the behaviour of his wife. As a woman of no status, and a person from the country with which China has a little abrupt relationship, she dared to make a direct claim that was a call for status that, at least in the eyes of the policemen she was not entitled to. Although she just asked for information, the way she did it was straightforward and demanding. Moreover, she made claims towards W, a highrank officer without any reference to his status and contribution to the community that she, indirectly belonged to. W's lian, contribution and professional integrity was not recognised. Moreover, she put a direct threat towards his mianzi, understood as a social status. He had no choice but to remind everyone in the room how "big" his mianzi was and act aggressively. Y1 also saw it as a chance to make his mianzi "bigger." As he was aspiring for a higher position, by displaying his toughness and status he already possessed, he needed W's recognition. He performed it not just for the ones interrogated but also for his superior. The only way out from this gridlock, was to demeanour the main 'culprit', G's wife (push her outside, agree with W that people 
in her country are not as well mannered as Chinese), and enhance W's face (recognising his status and contribution, display deference and apology, accepting "his rules"). Once all these have been performed, W was appeased to a degree, while Y1 kept being aggressive. He saw another chance to enhance his mianzi when $\mathrm{G}$ did not want to sit in the interrogation chair. However, he had to stop once ordered by W. The power relation was clear. The appeal to W's mianzi (apologies and recognition of status) with a hidden intention of appeal to his lian (being a human, zuo ren) could not be left without an answer. He then had no choice but to agree, and Y1 had to stop since his call for face enhancement, would cost W a substantial loss of face (giving up his status as a leader and a being a human). Y1's face was hurt at this moment. He could not fire back at W, but he tried to get the interpreter into a further exchange. He was largely ignored, in a superficially submissive manner. The interpreter could afford it since he enhanced W's face at this point. Further investigation was again a "face game." W was in constant need of his status recognition and appreciation for his work. It is not to say that he was not interested in handling the case properly. Quite to the contrary. He wanted to sort everything out and to obtain a clear answer. However, not only the answer did matter but the way it was supposed to be obtained did as well. The dynamics of the situation was clearly based on the perception of the space and a people in it as a hierarchical structure. This hierarchy had to be recognised and acknowledged. The behaviour of G's wife displayed a clear failure in this respect. The structure had to be then communicated to the ones who did not perceive it properly. Moreover, the right of high self-esteem of the officers, especially W needed to be acknowledged. This was this declared "trust" 33 in police's, especially W's "goodwill" and "professionalism" that gained interpreter his sympathy. The interpreter displayed an understanding of the signs and communicates sent by W that represented the structure and a demand for a certain position in the whole structure. Without this, interrogation would go nowhere and would probably ended with $G$ being deported. Face is a dynamic structure, and it needs to be remembered that claim for further recognition may be put forward at any time. W demand to visit to the school to inspect G's computer could be questioned as a fully legal action. However, denying him this would harm his face, and he would certainly find a way to retaliate. He was convinced once he could check the content of the relevant file. Then came the idea about the phone, probably coming from Y1. Again, it would be legally justified to say "no." However, it would hurt his face again, and, as he openly stated he would display his authority through legal actions. So being deferent enhanced his face again. The final, and unexpected enhancement came from learning about the status of the interpreter. As educated people have

33 More about the importance of 'trust' in interacting in Chinese social landscape and its relation to mianzi and guanxi see: P.J. Buckley, J. Clegg, Hui Tan, Cultural awareness in knowledge transfer to China - The role of guanxi and mianzi, "Journal of World Business" 2006, vol. 41, issue 3, pp. $275-288$. 
always been in a high-esteem in China, being previously acknowledged by the person that occurred to be of a certain achievements in this respect was of a great value to W. He acknowledged that by suggesting a dinner and keeping in touch. The interrogation was then not just a way of finding about the actual situation regarding student's accusations. It was vital for the police to have case solved, but not just for the sake of the truth. It was a way more important to be acknowledged as ones who are fulfilling their duties and are proper people for the job, enhancing lian. Moreover the recognition of status was crucial for the successful communication with the policemen. There was another game going on between W and Y1. For some not familiar with Chinese reality observer, it could look like a "bad cop vs good cop" settings. The difference was, $\mathrm{Y} 1$ in the end had to submit himself to W's orders and could be ignored by the interpreter. Of course, as long as the interpreter did not impose a direct threat to his face, what would a threat to the face of the entire police, including W. So there was then not only a circular, but actually multi-circular process going on. Face under consideration was then moral, but also social, it was individual, but also collective; it was imposed by the external reality, but also a source, and a display of a particular identity. W displayed his status and also claimed it. He also wanted to be perceived as being a "proper human", a man for a job. He could not tolerate any compromises in this respect, since he would not be able to control Y1. Y1 on his behalf needed W's recognition, so he could not go against him, a person of "bigger" (more significant?) face. Y2, played also an important role. Despite being rather bored with the whole situation, he had a lower position than two others, so he was enhancing their mianzi. Especially W needed him. Really important individuals have more than one servants, so he was an indispensable part of the puzzle.

\section{Conclusion and recommendations}

Quite a few of expats living in China experienced at least once a situation of being left in puzzlement after dealing with people of certain social status. State officials, businessmen and even university professors might make one's unfamiliar with Chinese communication codes not only feeling lost but unintentionally make often an easy case into even open hostility. It is easy to sum it up by saying: "They are weird/irrational/ don't speak English" and so on. However, such a conclusion does not bring us any closer to the actual understanding of the situation. The situation described and briefly discussed above was more than a typical case in which a lack of understanding of the nature of the interaction could have led to rather miserable results. As I tried to point out above, what did matter in the whole process was not an expected outcome, but the way it was supposed to be obtained. For a one with some experience with the way Chinese people communicate and familiar with core social values of Chinese society, 
it was more than obvious that the whole interrogation would be a display of power, social status and an open claim for recognition. One could say "display of face and a call for its enhancement." However, mistaken would be one who tried to stop here. There was something more in the whole process than just "power struggle." Ideas put forward by Hwang Kuang-Kuo seem to be only a part of the whole picture. ${ }^{34}$ This call for acknowledgement also had a bit deeper dimension. Especially in case of W, it was to demonstrate that his social status is not just an outcome of a certain power game but was also an outcome of certain at least 'professional' if not "moral" accomplishments. It was not just a call for mianzi enhancement, but also for recognition of lian, using Hu's terminology. There are then two dimensions involved in the single action. So, as it is justified to analyse the whole occurrence using two sets of terminology, it does not mean that the two are separate from each other and that the meaning and application of two terms do not overlap each other. So Ho seems to be right when he points out that the distinction is more "technical" than substantial. ${ }^{35}$ Moreover, from how $\mathrm{W}$ and $\mathrm{Y} 1$ were concerned about displaying their status and gain recognition, we may find Oatey's position regarding face quite plausible. What they were concerned about was their images in the eyes of others. Also, their images of themselves were at stake here. What mattered was if the way they should be perceived, or the way they perceived themselves was recognised and acknowledged. All these were sources of their identity, psychological state of finding one as an integral social unit that can remain in understandable and acknowledged relations with other units and the world around. They were not very much concern if the way they were proceeding the interrogation was in accordance with let's say western standards of individual rights, to privacy for instance. These were not parts of their self-image, the way they perceived their social and moral qualifications. Even after all, quite friendly W completely dismissed any request for any special treatment for $G$ due to his health problems. What made him change his mind was a remark, made in a very deferent manner about the possibility of performing his duties, displaying his face properly. It does not exclude "power game" happening at the same time, like the one between W, Y1 and the interpreter. However, what was at the bottom was that need for self-image, of course, built on others recognition and acclamation. Face is then not only a crucial factor in the power struggle, but also a part of individual, and collective identity. Again, saying that face is just a self-imaged claimed from others would be at least to a degree a simplification. The face display and claim for face recognition were by its virtue, not just a self-image as such. It was rather a way of communicating social structure, relations between involved elements and the expected/required behaviour and possible retribution in case all these were not recognised and acknowledged. ${ }^{36}$ Face, regardless

${ }^{34}$ K.K. Hwang, Face and Favor...

35 D.Y.F. Ho, On the Concept of Face...

36 S. Ting-Toomey, Translating conflict... 
mianzi or lian is a way of communicating socio-cognitive structures that are specific for a certain culture, and as such require a specific mode of communication. They not only cannot be understood but simply cannot be communicated if the specific mode of transferring information is not applied. Face is then an integral element of a sociohistorically determined cognitive and axiological structure that takes an appeal to its unique ("this is China") and long-lasting, as W was keen to remind, nature and sociomoral sanction as a source of legitimacy. It is then a self-preserving system which crucial features become legitimised by the appeal to this uniqueness, long-lastingness and socio-moral nature. Even though they can be modified and adapted, the fact of constant modification and adaptation does not make them more prone to change and external influence. Quite to the contrary, the socio-moral nature of the idea itself structures the experience to the degree, beyond which operating it is hardly possible. Face, as it is being displayed, claimed, enhanced and hurt is then medium through which effective communication, in this particular setting, is being performed. Remembering about it is then a sine qua none condition for any form of communication.

\section{STRESZCZENIE}

\section{POJECIE TWARZY I KOMUNIKACJA W KONTEKŚCIE CHIŃSKIM}

W artykule autor analizuje rolę i wszechobecną naturę koncepcji twarzy (mianæi, 面子; lian, 脸), jaka funkcjonuje w chińskiej komunikacji. W tym celu w pierwszej kolejności analizuje znaczenie i różne interpretacje pojęcia we współczesnej nauce. Dwie następne części zawieraja analizę przypadku formalnego policyjnego przesłuchania, w którym „gra twarzy” odegrała kluczową rolę. W ostatniej części autor powraca do głównych zaprezentowanych wcześniej koncepcji, poddając je analizie w kontekście przedstawionych danych. Autor stara się wskazać propozycje wykorzystania koncepcji twarzy w życiu codziennym przeciętnego obywatela i jej znaczenie w komunikacji międzykulturowej. „Chińska twarz” nie jest jedynie uwarunkowanym historycznie przedstawieniem wartości socjologiczno-kulturowych. W życiu codziennym stanowi ona dogodny środkiem komunikacji, który w obliczu bardzo skomplikowanej struktury socjologicznej umożliwia uporządkowanie doświadczeń poznawczych. Autor pokazuje, że pojęcie twarzy jest wpisane w trwała strukturę, która będzie odgrywać istotną rolę w przyszłości. W związku z tym jego znaczenie w międzykulturowej komunikacji z chińskim kręgiem kulturowym nie może i nie powinno być pomijane. 